Int. J. Dev. Biol. 52: 511-522 (2008)

doi: $10.1387 / \mathrm{ijdb} .072532 \mathrm{mb}$

\title{
The role of the acrosomal matrix in fertilization
}

\author{
MARIANO G. BUFFONE ${ }^{1}$, JAMES A. FOSTER ${ }^{3}$ and GEORGE L. GERTON ${ }^{1,2, *}$ \\ ${ }^{1}$ Center for Research on Reproduction and Women's Health, ${ }^{2}$ Department of Obstetrics and Gynecology, University of Pennsylvania \\ School of Medicine, Philadelphia, PA, USA and ${ }^{3}$ Department of Biology, Randolph-Macon College, Ashland, VA, USA
}

\begin{abstract}
Mammalian sperm must have properly formed acrosomes to be fully functional in the process of binding and penetrating the zona pellucida (ZP), the extracellular matrix surrounding the egg. There is much evidence to raise doubts about the old "bag of enzymes" paradigm of acrosomal function, although this is the model that seems to prevail. We concur with other scientists that acrosomal exocytosis is not an all or none event where the acrosome is either "intact" or "reacted". As determined by transmission electron microscopy of human sperm undergoing acrosomal exocytosis, six stages can be identified, with the intermediate ones involving loss of acrosomal matrix material. In the mouse, there is a temporal relationship among four stages of acrosomal exocytosis. Numerous evidences suggest a more complex role for the acrosome in fertilization in which the acrosomal matrix is a scaffold for sperm-ZP interactions that self-regulates by a controlled disassembly mechanism.
\end{abstract}

KEY WORDS: acrosome, sperm, zona binding, zona pellucida, sp56

\section{Introduction}

The acrosome (Gr. akros = extreme or tip, soma = body) is a Golgi-derived exocytotic organelle located at the tip of the sperm head from many mammalian species. Mammalian sperm must have properly formed acrosomes to be fully functional in the process of binding and penetrating the zona pellucida (ZP), the extracellular matrix surrounding the egg. Men or mice carrying mutations affecting the formation of the sperm acrosome are infertile or display subfertility (Dam et al., 2007, Kang-Decker et al., 2001, Lin et al., 2007, Schill, 1991, Sotomayor and Handel, 1986).

In this review, we will address the structure and function of the particulate aspect of the acrosome, the acrosomal matrix. We will first discuss the features of the acrosomal matrix including some of its protein components. Next we will examine some of the frequently overlooked properties of the acrosomal matrix. Finally, we will incorporate these concepts into an alternative perspective for viewing the events occurring at the interface between the sperm and the zona pellucida. It is our goal to challenge the reader to consider the nature of the acrosomal matrix when developing paradigms for sperm-zona interactions. For example, does the acrosomal matrix progress through various stages (condensed, gel-like, soluble) following its exposure to the extracellular milieu? Do all assays of acrosomal status (intact, reacted, other) report on the same property (plasma membrane integrity, presence of acrosomal components, existence of an ionic or $\mathrm{pH}$ gradient across the plasma membrane)? What molecules are involved in sperm-zona adhesion and where are they located?

\section{Acrosomal biogenesis and morphology}

Acrosomal biogenesis begins in the late pachytene spermatocyte phase of meiosis and continues throughout the first half of spermiogenesis, the haploid phase of spermatogenic differentiation in the seminiferous tubules of the testis (Anakwe and Gerton, 1990, Escalier et al., 1991, Kashiwabara et al., 1990). Initially, proacrosomal vesicles are formed in the perinuclear region near the Golgi apparatus of pachytene spermatocytes. As a result of the meiotic cell divisions, these vesicles are distributed to the four daughter spermatids. In early spermiogenesis, these vesicles coalesce into a single granule that attaches to the round spermatid nucleus and continues to enlarge as Golgi-derived material is added to the developing acrosome. During the last half of spermiogenesis while the elongating spermatids are maturing, the Golgi ceases to contribute glycoconjugates to the acrosome and

\footnotetext{
Abbreviations used in this paper: AM, acrosomal matrix; OAM, outer acrosomal membrane; PABP, proacrosin binding protein; ZP, zona pellucida; ZPBP, zona pellucida binding protein.
}

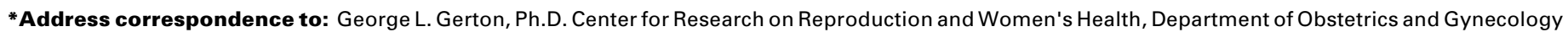

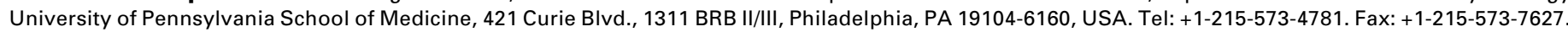
e-mail: gerton@mail.med.upenn.edu
}

Published online: 4 July 2008

$0214-6282 / 2008 / \$ 35.00$

(C) UBC Press

Printed in Spain 

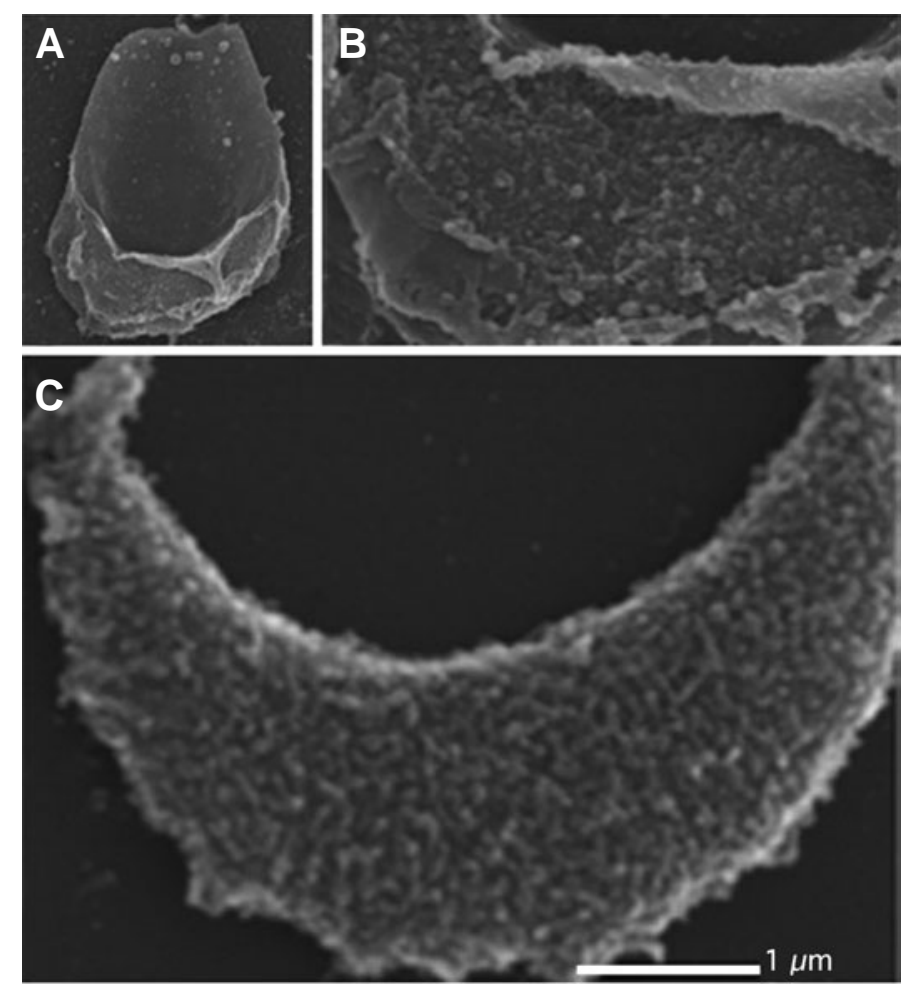

Fig. 1. Scanning electron micrographs of the acrosomal matrix in guinea pig sperm. The acrosomal matrix is visible where the membranes over the acrosome appear to have been disrupted (A). (B) An enlargement of (A). An acrosomal matrix (C) isolated by the method of Hardy et al., 1991 has a characteristic crescent shape and the same textured appearance as the acrosomal matrix seen within the acrosome of the cell in $(A, B)$

the acrosome-nucleus complex undergoes extensive morphological alterations to assume the shape that is 'characteristic for a given species' sperm. In some species, additional maturation of the acrosome occurs as the sperm transit the epididymis. In the case of a dramatic example, the guinea pig, the heads of testicular sperm entering the rete testis from the seminiferous tubules are quite planar, much like a flat hand (Fawcett and Hollenberg, 1963). As the sperm travel through the epididymis to the vas deferens, the acrosome transforms such that it resembles a cupped hand, where the fingers represent the apical segment of the acrosome and the remainder of the hand, the sperm nucleus. The acrosome forms a convex (dorsal) face with a bulge, a concave (ventral) surface, and a leading edge that tapers to a pronounced tip.

The acrosome of a mature sperm can be defined in terms of several structural compartments. Surrounding the lumen of the acrosome is the acrosomal membrane. This can be further delineated into the outer acrosomal membrane (OAM), which is in close apposition to the plasma membrane overlying the acrosome, and the inner acrosomal membrane (IAM), which is in tight association with the nuclear membrane (Eddy and O'Brien, 1994). During the course of acrosomal exocytosis, the OAM and plasma membrane fuse and are lost as hybrid membrane vesicles or as a fused membrane sheet. In some cases, an acrosomal ghost or shroud can be seen that consists of the membrane sheet or the vesicles held together by acrosomal matrix material (Bedford, 1998, Lea et al., 2001). The lumen of the acrosome contains soluble components and a particulate structure known as the acrosomal matrix (Foster et al., 1997, Kim et al., 2001a, Olson and Winfrey, 1994, Westbrook-Case et al., 1995). As discussed below, morphological subcompartments within the acrosomal matrix of some sperm can be clearly distinguished as regions of different density by electron microscopy or zones containing different acrosomal antigens as detected by immunoelectron microscopy.

\section{Operational definition of "acrosomal matrix"}

Originally, the use of the term "acrosomal matrix", referred to the electron dense material within the lumen of the acrosome. However, as studies were performed to determine the biochemical nature of the acrosome, the operational definition of the acrosomal matrix has become the particulate, membranefree component of the acrosome that remains following treatment of sperm with the non-ionic detergent Triton X-100 (Fig. 1). For biochemical characterization, acrosomal matrices have been dislodged from guinea spermatozoa and hamster by shaking the cells in a $\mathrm{pH} 5.2$ buffer containing Triton X-100 and protease inhibitors, and enriching the particulate matrices on a glass-bead column (Huang et al., 1985, Hyatt and Gwatkin, 1988). Under these circumstances, a morphologically intact but membrane-less acrosomal matrix can be isolated free of the remaining sperm heads and tails. The same extraction conditions can be applied to mouse sperm to demonstrate the presence of particulate acrosomal matrix within these smaller acrosomes; under these conditions the acrosomal matrix remains laminated on the apical aspect of the sperm head (Kim etal., 2001a)."The ability to isolate acrosomal matrices enabled several laboratories to begin characterizing their protein composition and to study how the matrices behave once they are exposed to the extracellular milieu.

\section{Protein composition of the acrosomal matrix}

The composition of the acrosomal matrix is limited in the number of different proteins present. Proteases, glycosidases, and various binding proteins can be found there. In fact, several ZP binding proteins are present within the acrosomal matrix. Most acrosomal matrix proteins appear to have orthologues in other species. Below we present a brief overview of some of the more commonly studied or better known acrosomal matrix components.

\section{Proacrosin}

The serine protease zymogen proacrosin is the quintessential acrosomal protein. For many years, the active enzyme, acrosin, was thought to be an essential zona lysin that enables the sperm to penetrate the ZP. Creation of mice null for the proacrosin gene demonstrated that this protease is not required for fertilization (Baba et al., 1994a). However, the penetration of the ZP by sperm lacking proacrosin is impeded, apparently due to a delay in dispersing the acrosomal matrix (Adham et al., 1997, Yamagata et al., 1998b). Thus, acrosin may process other proteins in the acrosome and on the membranes during acrosomal exocytosis (Honda et al., 2002). Acrosin has also 
been characterized as a ZP-binding protein (Howes and Jones, 2002, Jones and Brown, 1987, Moreno et al., 1998, Mori et al., 1995, Richardson and O'Rand, 1996, Williams and Jones, 1991).

\section{Proacrosin binding protein (PABP)}

Also known as sp32, this protein has been identified in a number of species (Yi and Polakoski, 1992). It has been most extensively studied in porcine sperm where it significantly accelerates the autoactivation of proacrosin at a basic $\mathrm{pH}$ in vitro and alters the activation pathway of proacrosin. When PABP is present, a $49-\mathrm{kDa}$ acrosin intermediate accumulates from the activation of the 55- and 53-kDa proacrosins, instead of a 43-kDa acrosin intermediate (Baba et al., 1994b).

\section{AM67/sp56/ZP3R}

Originally described by Bleil, Wassarman, and colleagues, sp56 is a binding protein for ZP3, one of the three ZP proteins (Bleil and Wassarman, 1990, Bookbinder et al., 1995, Cheng et al., 1994, Cohen and Wassarman, 2001). In the mouse, the gene encoding sp56 has been assigned the symbol Zp3r (for ZP3 receptor). ZP3R/sp56 is an oligomeric member of the complement regulatory protein family (Bookbinder et al., 1995) and is more closely related to the guinea pig acrosomal matrix protein AM67 than it is to mouse complement 4-binding protein (Foster et al., 1997). Initially, ZP3R/sp56 was characterized as a plasma membrane protein but subsequent studies demonstrated that this protein, like guinea pig AM67, is intra-acrosomal (Fig. 2) and a component of the acrosomal matrix (Cheng et al., 1994, Foster et al., 1997, Kim et al., 2001a, SuzukiToyota et al., 1995).

\section{AM50/p50/apexin/NPTX2}

Three laboratories independently identified AM50/apexin from guinea pig sperm (Noland et al., 1994, Reid and Blobel, 1994, Westbrook-Case et al., 1994). Additional studies in the human and rat identified the orthologues (neuronal pentraxin 2 [NPTX2] or Narp) from neuronal tissues (Hsu and Perin, 1995, Tsui et al., 1996). Pentraxins are multimeric proteins that usually form decamers and come in two basic flavors: classical pentraxins (C-reactive protein, serum amyloid $\mathrm{P}$-component) and long pentraxins (PTX3, AM50). They have been implicated in innate immunity, inflammation, matrix deposition, and female fertility (Garlanda et al., 2005). As a consequence of acrosomal exocytosis, AM50 monomers are processed from a 50,000 $M_{r}$ monomer to a 43,000 Mrmonomer (Kim etal., 2001b, WestbrookCase et al., 1995).

\section{ZPBP1/sp38}

Zona pellucida binding protein 1, ZPBP1/sp38, was first identified by Baba and co-workers (Mori et al., 1993, Mori et al., 1995) and purified from detergent extracts of porcine epididymal sperm. This protein also demonstrated the ability to bind the pig ZP in a calcium-dependent manner. The binding of sp38 to ZP could be inhibited by proacrosin, suggesting that these two proteins competitively interact with ZP during early steps of fertilization. Subsequently, the bovine orthologue has been isolated and characterized from a specialized domain of the acrosomal matrix, the inner acrosomal membrane extracellular coat, and shown to possess properties similar to the porcine protein (Yu et al., 2006). More recently, the mouse gene for ZPBP1 and its paralogue ZPBP2 have been identified and mice null for these genes have been created (Lin et al., 2007). ZPBP1-null male mice are sterile while ZPBP2-null male mice are subfertile. The defects in the germ cells are not limited to their ability to bind and penetrate the ZP; sperm from the null mice have dysmorphic acrosomes and heads, as well as other defects in the seminiferous tubules, indicating that these proteins have important functions during spermiogenesis. ZPBP paralogues are also found in amphibians, birds, and other mammals (Lin et al., 2007).

\section{Zonadhesin}

Zonadhesin was initially identified and isolated from boar sperm as a membrane protein that binds in a species-specific manner to the ZP of the egg (Hardy and Garbers, 1995). Subsequently, cDNAs or genes have been partially or completely sequenced from mouse, human, rabbit, hamster, and non-human primates (Bi et al., 2003, Gao and Garbers, 1998, Gao et al., 1997, Hardy and Garbers, 1995, Herlyn and Zischler, 2007, Lea et al., 2001, Olson et al., 2004) Testicular porcine zonadhesin is extractable with non-ionic detergents and would not be considered a component of the acrosomal matrix by the operational definition listed above ( $\mathrm{Bi}$ et al., 2003). In round and elongating spermatids, zonadhesin localizes to the developing outer acrosomal membrane. However, during the course of sperm transit the epididymis, most of the protein becomes incorporated into an extraction-resistant fraction, thus meeting the criteria for being an acrosomal matrix protein. Subsequent immunoelectron microscopy studies localized zonadhesin to
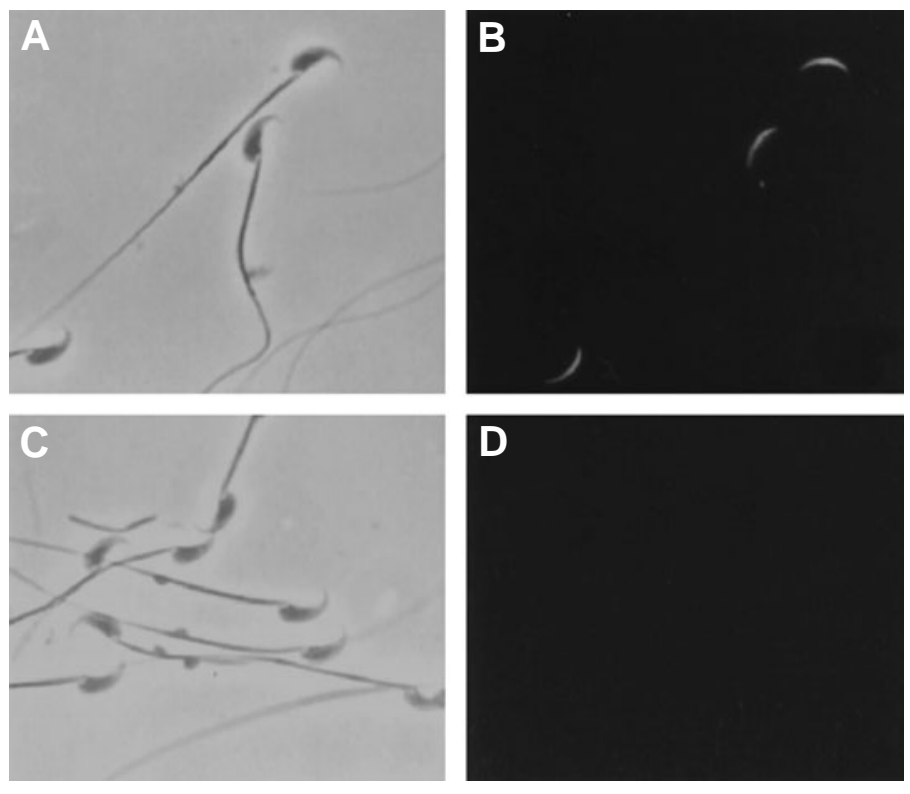

Fig. 2. Indirect immunofluorescence of paraformaldehyde-fixed and live mouse sperm. Shown are corresponding phase-contrast $(\mathbf{A}, \mathbf{C})$ and immunofluorescence (B,D) micrographs of mature mouse sperm immunostained with anti-sp56 monoclonal antibody 7C5. Paraformaldehyde-fixed sperm $(A, B)$ showed bright acrosomal fluorescence localization of sp56 (B), whereas live unfixed sperm $(C, D)$ showed no immunofluorescence (D). Reproduced from Foster et al. (1997). 
the perimeter of the acrosome in intact ejaculated boar spermatozoa while in sperm with disrupted acrosomal membranes, the protein was detected at the leading edge of acrosomal matrix (Bi et al., 2003).

\section{SP10}

SP-10 is a testis-specific protein that is initially expressed post-meiotically in round spermatids (Herr et al., 1990, Kurth et al., 1991, Kurth et al., 1993) where it is localized in the acrosome and is a component of the acrosomal matrix (Foster and Herr, 1992, Olson et al., 1997). In humans a 45,000 $M_{r}$ precursor is proteolytically processed to polymorphic forms ranging from

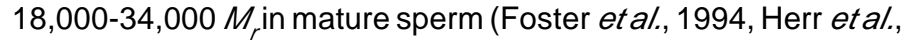
1990, Herr et al., 1992). SP-10 antibodies interfere with sperm binding to the zona pellucida in bovine in vitro fertilization, suggesting that SP-10 functions in sperm-zona pellucida interactions (Coonrod et al., 1996).

\section{Other acrosomal matrix proteins}

In addition to the proteins summarized above, there are several other proteins that have been described as components of the acrosomal matrix. These include, but are not limited to, the following proteins. SLLP1 has been identified as a unique, nonbacteriolytic, c (chicken or conventional type) lysozyme-like protein present in the acrosome of human sperm and it has been proposed as a potential receptor for the egg oligosaccharide residue $\mathrm{N}$-acetylglucosamine (Mandal et al., 2003). $\mathrm{N}$ acetylglucosaminidase has been isolated from a purified acrosomal matrix fraction of hamster spermatozoa (NagDas et al., 1996a). In the mouse, it facilitates sperm penetration through the zona (Miller et al., 1993b). SAMP14, a member of the Ly-6/ urokinase-type plasminogen activator receptor superfamily of receptors, localized to outer and inner acrosomal membranes as well as the acrosomal matrix of ejaculated human sperm (Shetty et al., 2003). It remains exposed on the inner acrosomal membrane following exocytosis. Equatorial segment protein (ESP) is a biomarker for a specialized subcompartment of the acrosomal matrix, localizing to the equatorial segment of ejaculated human sperm (Wolkowicz et al., 2003). ESP can be traced through all stages of acrosome biogenesis; it has recently been proposed to be involved in sperm/egg binding and fusion at the level of the oolemma (Wolkowicz et al., 2007). This subset of studies concerning proteins of the acrosomal matrix illustrate the diversity of protein functions within this important structure.

\section{Compartmentalization within the acrosomal matrix}

The acrosomal matrix itself is compartmentalized into different domains containing distinct subsets of proteins. Topographically, specific acrosomal proteins have been localized to defined domains within the acrosome (Foster et al., 1997, Olson and Winfrey, 1994, Olson et al., 1988, Tanii et al., 1994, WestbrookCase et al., 1994). This has been shown mainly in species with large acrosomes (guinea pig and hamster) but has also been seen in small acrosomes (mouse and human). Thus, guinea pig sperm represent an attractive model for defining the structure and function of individual acrosomal domains.

Like other mammalian sperm, the guinea pig sperm acrosome consists of an equatorial segment that delimits the posterior boundaries of the acrosome and encircles the nucleus, a principal segment (a thin, perinuclear region), and an apical segment that extends beyond the nucleus (Eddy and O'Brien, 1994). However, in the guinea pig, the apical segment is much larger and compartmentalized than in most mammals (Fawcett, 1975a, Fawcett, 1975b, Fawcett and Hollenberg, 1963). Three zones of differing electron density can be differentiated in the apical segment of epididymal sperm: the electron-lucent dorsal bulge (M1), a zone of intermediate electron density (M2), and the most electrondense region (M3) (Olson et al., 1987) (Fig. 3). The soluble acrosomal enzyme dipeptidyl peptidase II and matrix component AM67 are localized in the M1 zone (Foster et al., 1997, Talbot and DiCarlantonio, 1985) while proacrosin is localized almost exclusively in the most electron-dense regions (M2 and $M 3)$ of the acrosome (Hardy et al., 1991). Westbrook-Case et al. (1994) published the initial characterization of AM50, a protein of the apical segment of guinea pig sperm. This protein is restricted to the ventral domain (M3) of the acrosomal matrix and is proteolytically processed during the acrosomal exocytosis. Autoantigen 1, a soluble acrosomal protein, is distributed throughout the whole acrosome with a slightly higher concentration in the denser regions (Hardy et al., 1991). Both autoantigen 1 and proacrosin are found in the principal segment, but neither is present in the equatorial segment of the acrosome.

In other species's sperm with smaller acrosomes, it may be difficult to see different domains without using immunological location techniques at the level of the electron microscope. For example, porcine and human sperm have smaller acrosomes that do not exhibit the prominent domains seen by transmission electron microscopy in guinea pig sperm. By immunoelectron microscopy, zonadhesin localizes to the perimeter of the acrosome in intact ejaculated boar spermatozoa or cauda epididymal hamster sperm, and to the leading edge of acrosomal matrix overlying cells with disrupted acrosomal membranes (Bi et al., 2003, Olson et al., 2004). On the other hand, SP-10 is most abundant within the principal segment and posterior bulb of the equatorial segment of the human sperm acrosome (Foster et al., 1994).

\section{How acrosomal matrix structure influences physiologi- cal function}

\section{Acrosomal matrix stabilization}

The existence of an acrosomal matrix comprised of proteins in different domains suggests that these proteins interact with each other to form the particulate complex. This is supported by studies of the biochemical structure of the bull and hamster sperm acrosomal matrix. In one investigation using bovine spermatozoa, a complex of the acrosomal matrix in association with the outer acrosomal membrane was isolated and it was demonstrated that this complex could bind proacrosin in a dose-dependent manner (NagDas etal., 1996b). Concentrating on proacrosin and $\mathrm{N}$-acetylglucosaminidase of the hamster sperm acrosomal matrix, NagDas et al. (1996a) examined how these enzymes interacted with the acrosomal matrix. Both hydrolases could be extracted from the matrices with high salt $(0.5 \mathrm{M} \mathrm{NaCl})$. The residual acrosomal matrix preparation after this step retained the property to bind proacrosin and $\mathrm{N}$-acetylglucosaminidase and, in a blot overlay, proacrosin bound to proteins with molecular weights of 29,000 and 24,000 . These experiments suggest that 
Fig. 3. Immunoelectron microscopic localization of AM67 in the M1 (dorsal bulge) domain of guinea pig sperm. The immunogold particles (arrows) were found solely within the M1 (dorsal bulge) domain of the lumen of the acrosome. In general, the gold particles were excluded from spherical bodies within this region. No staining was observed in the M2 (intermediate zone) or M3 (ventralzone) region. Reproduced from Foster et al. (1997).

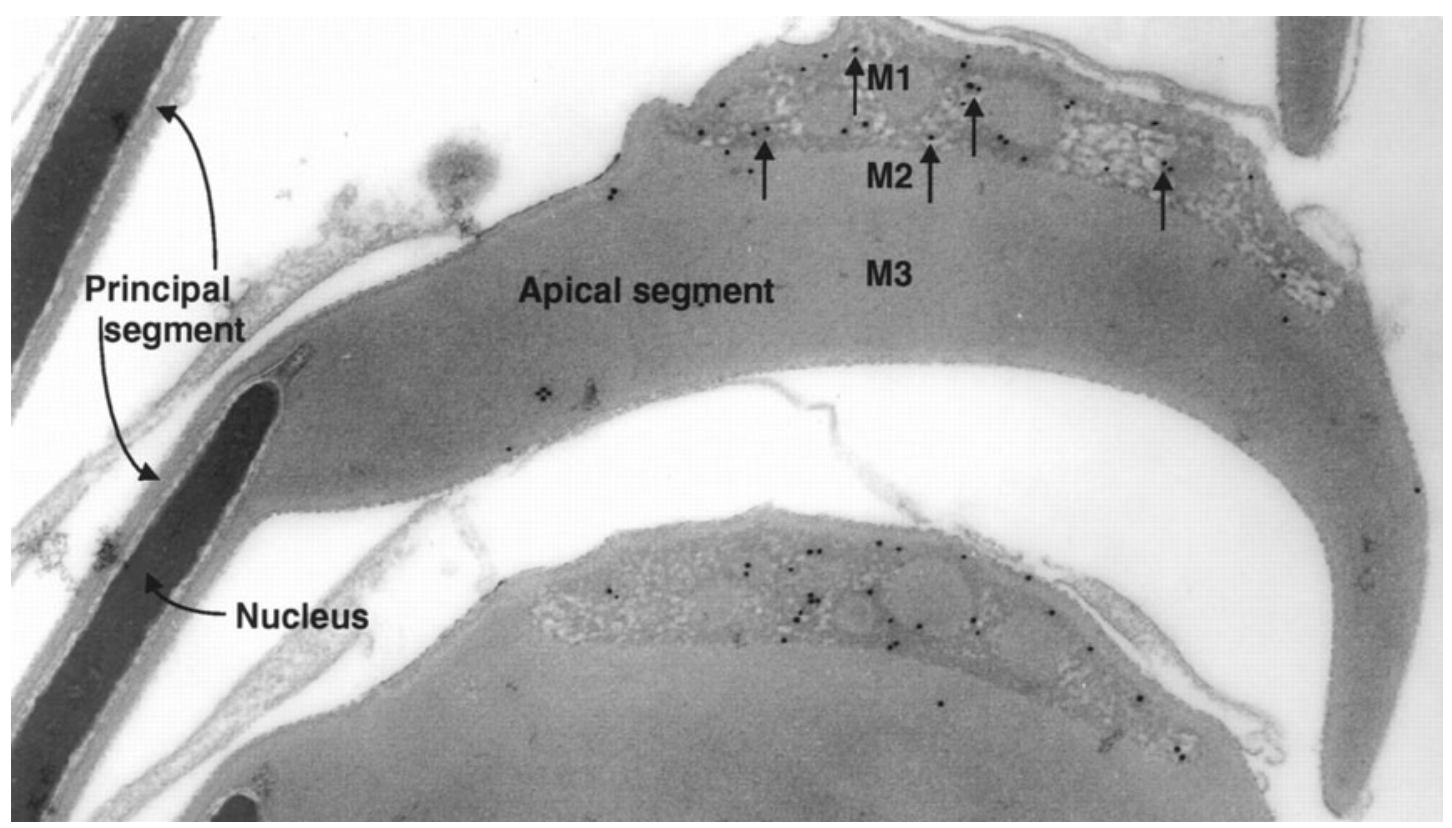

the acrosomal matrix proteins contain information for self-assembly into a large complex within the acrosome. Hardy et al. (1991) also recognized the disulfide-bonded nature of some of the acrosomal matrix polypeptides. Specifically, proteins such as AM50 and AM67/sp56 also form high molecular weight oligomers that contain monomers with intermolecular and intramolecular disulfide bonds (Foster et al., 1997, Noland et al., 1994). As a result of the oligomeric nature of these proteins, they are predicted to be multivalent and may be able to help stabilize the acrosomal matrix by non-covalent cross-linking of protein components.

The genetic deletion of specific acrosomal matrix proteins can have a detrimental effect on the structure of acrosome and the function of the sperm (Lin et al., 2007). When the Zpbp1 and Zpbp2genes were disrupted in mice, males lacking ZPBP1 were sterile, with abnormal round-headed sperm morphology and no forward sperm motility. The absence of ZPBP1 prevents proper acrosome compaction, acrosome fragmentation, and disruption of the Sertoli-spermatid junctions. Males null for ZPBP2 are subfertile; their sperm exhibit aberrant acrosomal membrane invaginations, and reduced ability to penetrate zona pellucida.

\section{Acrosomal matrix expansion and dispersion}

The stability of the acrosomal matrix is dependent upon its sequestration from the extracellular milieu. The interior $\mathrm{pH}$ of the acrosome is acidic (Meizel and Deamer, 1978, Nakanishi et al., 2001) and this serves to maintain proteases such as proacrosin in an inactive state (Brown and Harrison, 1978, Honda et al., 2002, Noland et al., 1989). As mouse sperm undergo capacitation, the acrosomal pH starts to alkalinize (Nakanishi et al., 2001). Whether this is related to the initial swelling or decondensation of the acrosomal matrix seen in the early phases of acrosomal exocytosis has yet to be determined (Nagae et al., 1986, Yudin et al., 1988). When the $\mathrm{pH}$ of the acrosome increases during the course of acrosomal exocytosis, proacrosin becomes activated. The conversion of proacrosin to acrosin apparently is then involved in the proteolytic processing of some of the acrosomal matrix components since acrosin-null mice exhibit a delayed dispersal of the acrosomal matrix (Adham et al., 1997, Yamagata et al., 1998b). It is thought that the alkalinization of the acrosomal contents is dependent on an influx of calcium into the acrosome since digitonin-permeabilized guinea pig spermatozoa undergo acrosomal matrix dispersion in response to $2.0 \mathrm{mM} \mathrm{CaCl}_{2}$ (Noland, 1990).

During acrosomal exocytosis, some components of the acrosomal matrix undergo post-translational modifications coincident with their release from the acrosome. These events are associated with the disassembly or breakdown of the acrosomal matrix, probably involving proteolytic cleavage by acrosin. The alkalinization of the milieu surrounding the acrosomal matrix components leads to the proteolytic processing of proacrosin itself to active acrosin during acrosomal exocytosis in several species (Baba et al., 1994b, Brown and Harrison, 1978, Green, 1978, Meizel, 1972, Nuzzo et al., 1990, Tesarik et al., 1990). In guinea pig sperm, proacrosin is detected in immunoblots of mature sperm, but is not detected in A23187-treated sperm, suggesting that the protein (or at least certain antigenic sites) had been modified during acrosomal exocytosis (Kim et al., 2001b). Related to this conclusion, protease activity consistent with the activation of proacrosin to a lower molecular weight form of acrosin was detected in the soluble acrosomal components released from sperm during acrosomal exocytosis. Another guinea pig acrosomal matrix protein, AM50 $\left(50,000 M_{\lambda}\right)$ co-localizes with proacrosin in the $\mathrm{M} 3$ zone of the acrosomal matrix and is proteolytically processed to $\mathrm{AM} \mathrm{AR}_{\mathrm{AR}}\left(43,000 M_{\lambda}\right)$ coincident with its release from the sperm during acrosomal exocytosis (WestbrookCase et al., 1994). The conditions under which this cleavage pattern occurs are consistent with proteolysis by acrosin. In addition, the $\mathrm{AM} 50$ to $\mathrm{AM} 50_{\mathrm{AR}}$ cleavage occurs at acrosin-specific sites (Foster and Gerton, unpublished data), further evidence that this protease may function in the dispersion of the acrosomal matrix during acrosomal exocytosis. Thus, proteolytic activation of proacrosin and processing of AM50 corresponds with the disassembly of the acrosomal matrix during acrosomal exocyto- 
sis. AM67, the guinea pig homologue of mouse ZP3R, does not appear to undergo processing during $\mathrm{AM}$ disassembly in the guinea pig (Kim et al., 2001b).

In the mouse model, homologues of several guinea pig acrosomal matrix proteins (proacrosin, proacrosin-binding protein, and AM67/sp56/ZP3R) are present in the acrosome, but how these proteins are assembled into an acrosomal matrix is not currently understood. Resistance to extraction by Triton X-100 is a hallmark of AM proteins, and under these conditions it is possible to visualize a matrix-like material in the acrosome by indirect immunofluorescence (Kim et al., 2001a) and scanning electron microscopy (Fig. 4). Mouse sp56/ZP3R is converted to a lower molecular weight form coincident with its release from the sperm into the supernatant during the course of spontaneous acrosomal exocytosis (Kim, Buffone, and Gerton, unpublished results). While a mouse homologue of AM50 would be a prime candidate substrate for acrosin, so far this protein has not been detected in the sperm acrosome.

Taken as a whole, the acrosomal matrix contains a set of proteins that interact with each other to form the particulate structure within the membrane boundaries of the acrosome. Furthermore, additional studies suggest that some matrix proteins may interact with either the outer or inner acrosomal membrane proteins. As previously mentioned, zonadhesin, which is considered an acrosomal matrix protein in mature boar and hamster sperm is initially synthesized as an acrosomal membrane protein that becomes proteolytically processed and incorporated into the matrix as the spermatid/sperm matures (Bi et al., 2003, Olson et al., 2004). In addition, inner acrosomal membrane proteins such as CD46 (membrane cofactor protein) may also influence the dispersion of acrosomal matrix components during the course of acrosomal exocytosis; males null for CD46 display a higher incidence of spontaneous acrosomal exocytosis and heightened fertilizing ability, suggesting that CD46 may have some role in regulating sperm acrosomal exocytosis (Inoue et al., 2003).

The microenvironment existing around the acrosomal matrix also influences its properties. Besides $\mathrm{pH}$ and proteolysis, other aspects of the milieu around the sperm undergoing exocytosis may also influence the state of hydration of the matrix, causing it to function more like a gel and impacting the rate of diffusion of substances trapped in the matrix. In the case of various osmoticants, it is possible to obtain fusion of the outer acrosomal membrane with the plasma membrane without the loss of the acrosomal matrix; under these circumstances, the sperm must be examined by electron microscopy to demonstrate that membrane fusion occurred (Green, 1991).

\section{Zona adhesion}

The interaction between sperm and the ZP leads to the activation of sperm signaling events and consequently stimulates acrosomal exocytosis, which is marked by the fusion of the plasma membrane with the outer acrosomal membrane and the eventual release of the acrosomal contents (Yanagimachi, 1994). We refer the reader to other studies for a discussion of the communication between the sperm plasma membrane and the zona pellucida as well as the signaling pathways that are activated following these interactions (see for example the review by Kopf (2002)). For the purposes of this discussion we note that it is often presumed that the outer acrosomal and plasma membranes must be intact for sperm to be capable of recognizing and binding to the ZP. However, there are several reports in the literature that sperm at various stages of acrosomal exocytosis may be competent to bind to the ZP (Huang et al., 1981, Morales et al., 1989, Valdivia et al., 1999), suggesting that components from the interior of the acrosome, such as acrosomal matrix proteins or proteins on the inner acrosomal membrane, are also involved in the attachment of the sperm from some species to the zona. Indeed, some of the technical difficulty of establishing whether "acrosome-intact" or "acrosome-reacted" sperm bind to the ZP could have arisen due to the lack of appreciation of the acrosomal matrix and its exposure during intermediate stages of acrosomal exocytosis (see comments below concerning assays of acrosomal status).

A large number of sperm molecules have been demonstrated to have affinity for the ZP and to be involved in sperm-ZP interactions, these include attachment, binding, and penetration of the ZP. The Initial attachment is apparently not particularly species-specific (Bedford, 1977, Hartmann et al., 1972). This is followed by a tight binding between sperm and the ZP, which is species specific. Tight binding is differentiated from attachment
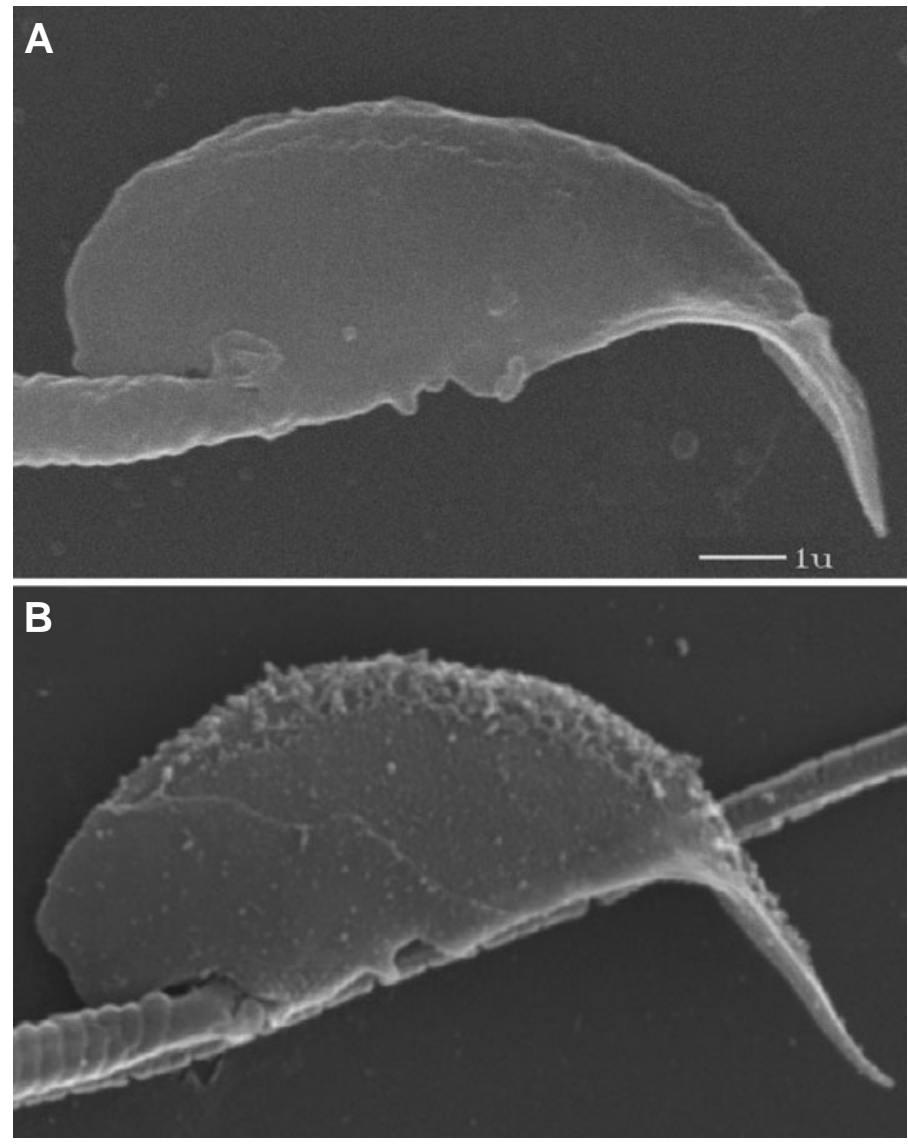

Fig. 4. Scanning electron micrographs of mouse sperm. (A) An acrosome-intact sperm shows some rippling of the membranes over the acrosome - perhaps in an early stage of acrosome reaction. (B) $A$ demembranated sperm that was treated with $1 \%$ Triton X-100 and protease inhibitors shows acrosomal matrix material along the anterior edge of the acrosome. 
by the resistance of sperm to being removed from the ZP by a physical force such as repeated pipetting or centrifugation (Bleil and Wassarman, 1980a, Saling and Storey, 1979).

It is not our purpose to compare and contrast the various zona pellucida-binding proteins and attempt to rank them in terms of relative importance. Of the many proteins that have been characterized as having some role in sperm-zona interactions; a few of these are truly associated with the surface of acrosome-intact sperm (such as $\beta$-1,4-galactosyltransferase (Shur and Hall, 1982) and SED-1 (Ensslin and Shur, 2003)) while others have been conclusively demonstrated to be components of the acrosomal matrix (see discussion above concerning specific acrosomal matrix components). The observations that so many acrosomal matrix proteins are involved in zona pellucida binding suggests that the interactions between the acrosomal matrix and the zona pellucida may be more akin to the interface between extracellular matrices of two interacting cell types rather than a lock and key mechanism displaying species-specific binding. The one exception may be zonadhesin which exhibits species-specific ZPbinding (Hardy and Garbers, 1995). In any event, sperm interaction with the ZP seems to be a very redundant process since the targeted deletion of SED-1, $\beta$-1,4-galactosyltransferase, ZPBP1, ZPBP2, or proacrosin does not necessarily result in a complete block to sperm-zona pellucida binding (Baba etal., 1994a, Ensslin et al., 2007, Lin et al., 2007, Lu and Shur, 1997). Rather, the subfertility or infertility seen with these gene targeted null animals results from defects in acrosome biogenesis, sperm morphogenesis, or disregulation of acrosomal exocytosis. Finally, although a protein like proacrosin may not be absolutely essential for fertilization, its presence may provide a advantage when competing with sperm lacking that protein (Adham et al., 1997).

\section{Zona penetration}

For many years, it was presumed that the process was enzymatic and dependent upon acrosin. However, in the mouse, this enzyme was eliminated as a possible zona lysin by the gene knockout studies from the Baba and Engel laboratories demonstrating that acrosin-null male mice are perfectly fertile (although fertilization is slower due to delays in the dispersal of the acrosomal matrix) (Adham et al., 1997, Baba et al., 1994a, Yamagata et al., 1998b). It has been proposed that other, membrane-bound proteases may be responsible for the penetration of the mouse zona pellucida (Honda et al., 2002, Yamagata et al., 1998a). Alternatively, some investigators have proposed that a nonhydrolytic process may be involved in penetrating the zona pellucida. For example, in the case of the abalone, the vitelline lysin functions in a stoichiometric fashion to disassemble the vitelline coat in a non-enzymatic manner (Lewis et al., 1982). Whether the mammalian sperm acrosome contains a protein with a similar activity has not been determined. The review by Bedford (1998) addresses inconsistencies in the literature that challenge the premise of zona enzymatic lysis. He discusses largely unnoted idiosyncratic features of the behavior of fertilizing spermatozoa in the eutherian mammals and analyzes the evidence for and the evidence against the enzymatic hydrolytic concept. The mechanism whereby a sperm penetrates the zona pellucida is surely in need of further study.

Another issue concerning the attachment and penetration of the zona pellucida by sperm is: once a sperm has bound to the ZP, how does it release from its initial site and move forward without falling off? It does not matter whether the sperm uses an enzymatic mechanism or some other way to create a path through the ZP, it still must release from the original point of contact and move forward without losing its "grip". We conceptualize that the nature of the acrosomal matrix may assist in the following manner. Any adhesion mediated by the acrosomal matrix will occur at the outer surface. As the matrix is gradually dispersed, proteins will be shed from the outer surface of the matrix, exposing new acrosomal matrix proteins for renewed adhesion to the zona pellucida. In this manner, the sperm may ratchet its way through the ZP as it is cyclically gripping new zona molecules while leaving behind a trail of shed acrosomal matrix proteins (Gerton, 2002).

\section{Role of ZP in acrosome interactions}

Other than being a barrier to sperm penetration, the zona pellucida influences sperm in two other ways. It contains ligands for sperm binding and signaling molecules that affect acrosomal exocytosis (Dean, 2007, Wassarman, 2005). In addition, assays in vitro have implicated some of the carbohydrate residues in mediating sperm-zona interactions in mice (Bleil and Wassarman, 1988, Florman and Wassarman, 1985, Miller et al., 1992) although recent studies with genetically manipulated mice call into question the roles of terminal galactose or $\mathrm{N}$-acetylglucosamine residues on the zona pellucida glycans (Williams et al., 2007). Following fertilization, egg cortical granules exocytose their contents, which modify the zona matrix so that additional sperm do not bind or penetrate (Ducibella et al., 1993, Miller et al., 1993a).

A recent paper published by Baibakov et al. (2007) challenges some aspects of the current model for events at the interface of the sperm and the zona pellucida. They showed that transgenic mouse sperm adhering to the zona of mouse eggs retained green fluorescent protein (GFP) for an extended period of time and proposed that sperm binding is not sufficient to induce acrosome exocytosis. The authors articulated a model of sperm-egg recognition in which the cleavage status of ZP2 determines whether the three-dimensional zona matrix will be permissive (ZP2 intact) or non-permissive (ZP2 cleaved) for sperm adherence, independent of fertilization and cortical granule exocytosis. The observed ability of sperm to remain acrosome-intact (as assayed by the presence of GFP) - despite hours-long adherence to ZP - is inconsistent with the ligand-receptor signal transduction model in acrosome exocytosis. To address this enigma, they proposed that a 'mechanosensory' signal generated by the penetration of the sperm through the zona pellucida matrix is sufficient for inducing acrosomal exocytosis. Unreconciled with this paradigm are the many, rather unambiguous observations that acid-solubilized ZP or purified ZP3 can stimulate acrosomal exocytosis (Bleil and Wassarman, 1980b, Bleil and Wassarman, 1983, Kopf, 2002). From our perspective, any model for acrosomal exocytosis must take into account the microenvironment at the site of spermzona pellucida interaction as well as the nature of the acrosomal matrix. For example, several studies have noted that GFP loss from the acrosomes of transgenic sperm on the zona is slow and interpret this to mean that acrosomal exocytosis has not occurred (Baibakov et al., 2007, Nakanishi et al., 1999). However, we have demonstrated an intermediate of mouse acrosomal exocytosis in which GFP-transgenic mouse sperm have exposed acrosomal matrix material (as demonstrated by the binding of beads coated 
with anti-sp56 antibodies) but still retain GFP in their acrosomes (Kim and Gerton, 2003). To explain the conundrum of sperm bound to the ZP retaining GFP, we envision that the biophysical environment at this site is not fully appreciated in these studies and that the glycoprotein nature of the acrosomal matrix and ZP components may create a gel-like microenvironment. If so, the diffusion of GFP away from the acrosomes of sperm embedded in the surface of the ZP may be impeded relative to sperm swimming free in solution. These observations underscore the need to challenge and re-evaluate current paradigms of spermZP interactions.

\section{Acrosome transitions and differential release of acrosomal proteins}

We concur with other scientists that acrosomal exocytosis is not an all or none event where the acrosome is either "intact" or "reacted". As determined by transmission electron microscopy of human sperm undergoing acrosomal exocytosis, six stages can be identified, with the intermediate ones involving loss of acrosomal matrix material while outer membranes appear to retain their integrity (Stock and Fraser, 1987, Yudin et al., 1988). In our own laboratory, we demonstrated that there is a temporal relationship among four stages of acrosomal exocytosis in the mouse: plasma membrane intact over the acrosome (Class 1), plasma membrane initiating fusion with outer acrosomal membrane with soluble components retained within the acrosome (Class 2 ), soluble acrosomal proteins lost but acrosomal matrix materials still present (Class 3 ), and most acrosomal components lost (Class 4) (Fig. 5). We conclude that these patterns represent successive transitional stages leading to the complete release of acrosomal components (Kim and Gerton, 2003). To visualize the soluble compartment, we utilized sperm from transgenic mice that carry soluble GFP in their acrosomes and, as a means to assess the exposure of acrosomal matrix components, we tested the ability of these sperm to bind beads coated with antibodies against sp56/ZP3R. The loss of GFP from the acrosomes and the binding of the beads by the sperm undergoing capacitation serve as indicators of different stages of acrosomal exocytosis suggesting that the exposure and release of soluble and matrix acrosomal proteins during spontaneous acrosomal exocytosis is not synchronous but is regulated as the sperm are incubated under capacitating conditions.
Based on this evidence and expanding on the work of others (DiCarlantonio and Talbot, 1988, Hardy et al., 1991), we proposed an alternative model for acrosomal exocytosis in mouse that considers the role of these intermediates of exocytosis during capacitation and sperm-ZP interactions and the particulate nature of the acrosomal matrix. We initially tested this hypothesis by examining materials released from guinea pig sperm undergoing acrosomal exocytosis in response to ionophore A23187 and comparing these with the proteins that remained associated with the sperm (Kim et al., 2001b). For instance, soluble compartment component CRISP2 (autoantigen1) was readily released from sperm during acrosomal exocytosis whereas acrosomal matrix protein AM50 remained with the sperm for a longer period of time. AM67 was also released more slowly than CRISP2 but was more readily solubilized than AM50 (in the supernatant fluid 10 minutes after AR induction).

In this differential time-released hypothesis, the AM components of sperm undergoing acrosomal exocytosis remain asso-
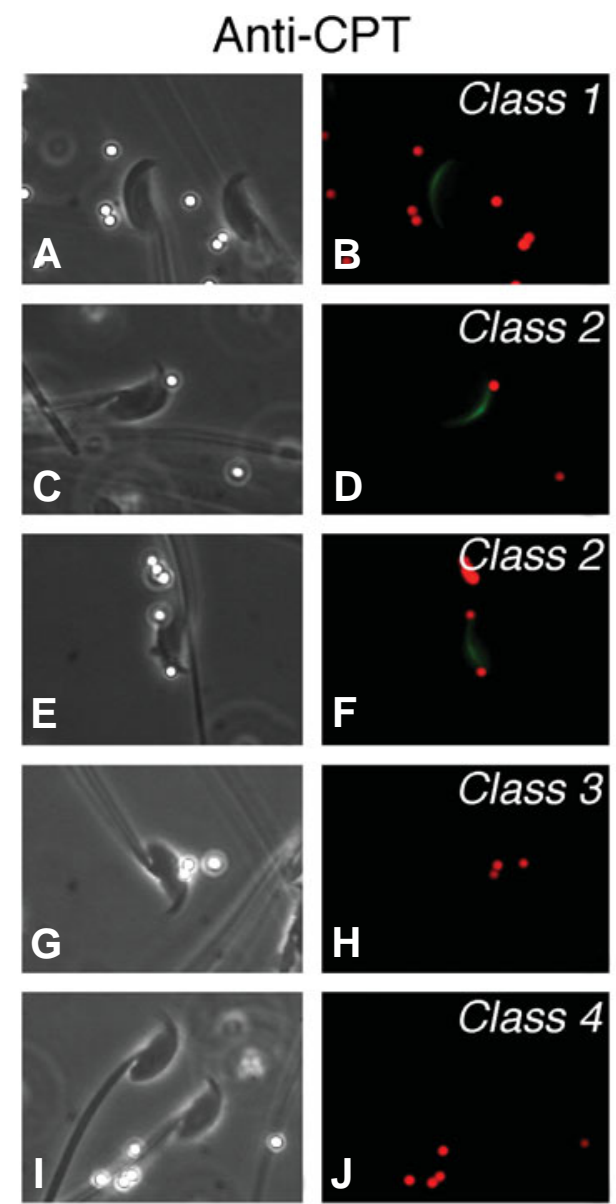

Anti-VYK

G
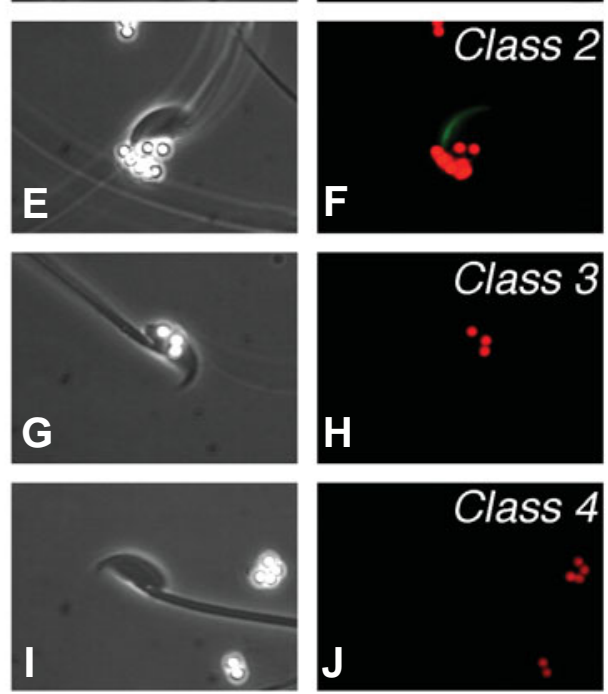

Fig. 5. Simultaneous detection of acrosomal GFP in transgenic mouse sperm and the binding of anti-sp56 antibody-coated FluoSpheres. GFP expression, driven by the proacrosin promoter, was targeted to the mouse sperm acrosome using the signal sequence and part of the $N$-terminus of proacrosin. Some sperm bound antibody-coated FluoSpheres, demonstrating the exposure of the acrosomal matrix in those sperm. Four classes of sperm were identified by this assay. Anti-CPT and anti-VYK are two peptide-specific antibodies to mouse sp56. Left panel: Anti-CPT-coated FluoSpheres; Right panel: Anti-VYK-coated FluoSpheres. Paired phase-contrast $\mathbf{( A , C , E , G , I ) ~ a n d ~ f l u o r e s c e n c e ~}$ (B,D,F,H,J) (GFP, green; FluoSpheres, red) images of sperm. Reproduced from Kim and Gerton (2003). 
ciated with sperm longer than soluble acrosomal proteins. The solubilization of the acrosomal matrix proteins may be coupled with post-translational modifications as they are released from the acrosome. As previously discussed in regard to the disassembly or breakdown of the acrosomal matrix, some proteins are proteolytically cleaved such as proacrosin, AM50 and ZP3R (Kim, Buffone, and Gerton, unpublished results) coincident with acrosomal exocytosis. Guinea pig AM67 is apparently not processed as a consequence of acrosomal exocytosis.

Based on work in the mouse, it is generally thought that the outer acrosomal and plasma membranes must be intact for sperm to be capable of binding to the ZP. Following what is called "primary binding", the OAM and PM fuse, releasing the contents of the acrosome (Yanagimachi, 1994). After the acrosomal contents are released, a second kind of interaction called "secondary binding" of the sperm to the ZP is mediated by proteins on the inner acrosomal membrane. The concept that the OAM and PM are intact when the sperm encounters the ZP arose over 25 years ago from studies in the mouse (Florman and Storey, 1982, Saling et al., 1979, Saling and Storey, 1979). However, there is evidence that guinea pig and human sperm in the process of undergoing acrosomal exocytosis may be competent to bind to the ZP (Huang et al., 1981, Morales et al., 1989). Furthermore, rabbit sperm isolated from the perivitelline space of fertilized eggs and, therefore, presumed to have undergone acrosomal exocytosis, are capable of fertilization in a second insemination (Valdivia et al., 1999). Thus, although the current perspective is that sperm must be "acrosome-intact" to bind to the ZP, one must consider these other findings and realize that the story may be more complex in other species.

One last point to emphasize is the need to consider the type of assay used in various investigations to assess the integrity of the acrosome with particular regard to scoring whether or not exocytosis has occurred. By standard light microscopy, the presence of an intact acrosomal matrix may make the acrosome appear to be intact even though fusion of the membranes has begun to occur. The same may be true with sperm that have been stained with Coomassie blue dye, antibodies against acrosomal matrix components, protease inhibitors, or lectins to detect acrosomal status (Foster et al., 1997, Larson and Miller, 1999, Morales and Cross, 1989, Tollner et al., 2000). Some reporter dyes detect ionic or $\mathrm{pH}$ gradients that exist between the external environment of the cell and the internal acrosomal compartment (Rockwell and Storey, 2000, Saling and Storey, 1979). Other methods utilize sperm from transgenic mice that express the green fluorescent protein in the acrosomes (Nakanishi et al., 1999). These latter two assays have a greater likelihood of determining whether the membranes are intact or not. Normally, the gold standard for acrosomal integrity has been transmission electron microscopy, but even this procedure has its shortcomings since only a small section of each cell is normally examined. The use of acrosomally targeted GFP as a reporter of membrane integrity was a major advance but our results indicate that acrosomal matrix proteins can be exposed in individual sperm without the complete or immediate loss of the GFP (Kim and Gerton, 2003). More recently, immunodetection of the exposure of the inner acrosomal membrane protein IZUMO1 has been used as another approach to assess acrosomal status (Yamashita et al., 2007). The main point to keep in mind is that it is difficult to compare studies that have not used the same method for assessing acrosomal integrity.

\section{Conclusion}

The complex organization of the acrosomal contents was beautifully demonstrated by electron microscopic images of the guinea pig acrosomal apical segment by Fawcett and Hollenberg (1963). Over the years many researchers have contributed to this field so that we now have a better understanding of the structure of the acrosomal matrix and the proteins that comprise it. However, even though there is much evidence to raise doubts about the old "bag of enzymes" paradigm of acrosomal function, this is the model that seems to prevail. In this review we have highlighted some of the work that contributes to a model of acrosomal function that suggests a more complex role for the acrosome in fertilization in which the acrosomal matrix is a scaffold for sperm-ZP interactions that self-regulates by a controlled disassembly mechanism. Future work will test this hypothesis.

\section{Acknowledgements}

This work was supported by grants (5 R01 HD041552 and 1 P30 ES013508) from the U.S. National Institutes of Health (to GLG), a Craigie Grant and Chenery Research Professorship from Randolph-Macon College (to JAF), and a fellowship (5 D43 TW000671) from the Fogarty International Center (to MGB).

\section{References}

ADHAM, I.M., NAYERNIA, K. and ENGEL, W. (1997). Spermatozoa lacking acrosin protein show delayed fertilization. Mol. Reprod. Dev. 46: 370-376.

ANAKWE, O.O. and GERTON, G.L. (1990). Acrosome biogenesis begins during meiosis: Evidence from the synthesis and distribution of an acrosomal glycoprotein, acrogranin, during guinea pig spermatogenesis. Biol. Reprod. 42:317-328.

BABA, T., AZUMA, S., KASHIWABARA, S.-I. and TOYODA, Y. (1994a). Sperm from mice carrying a targeted mutation of the acrosin gene can penetrate the oocyte zona pellucida and effect fertilization. J. Biol. Chem. 269: 31845-31849.

BABA, T., NIIDA, Y., MICHIKAWA, Y., KASHIWABARA, S., KODAIRA, K., TAKENAKA, M., KOHNO, N., GERTON, G.L. and ARAI, Y. (1994b). An acrosomal protein, sp32, in mammalian sperm is a binding protein specific for two proacrosins and an acrosin intermediate. J. Biol. Chem. 269: 10133-40.

BAIBAKOV, B., GAUTHIER, L., TALBOT, P., RANKIN, T.L. and DEAN, J. (2007). Sperm binding to the zona pellucida is not sufficient to induce acrosome exocytosis. Development 134: 933-43.

BEDFORD, J.M. (1977). Sperm/egg interaction: the specificity of human spermatozoa. Anat Rec 188: 477-87.

BEDFORD, J.M. (1998). Mammalian fertilization misread? Sperm penetration of the eutherian zona pellucida is unlikely to be a lytic event. Biol. Reprod. 59: 1275-87.

BI, M., HICKOX, J.R., WINFREY, V.P., OLSON, G.E. and HARDY, D.M. (2003). Processing, Localization, and Binding Activity of Zonadhesin Suggest a Function in Sperm Adhesion to the Zona Pellucida during Exocytosis of the Acrosome. Biochem. J. 375(Pt 2): 477-88.

BLEIL, J.D. and WASSARMAN, P.M. (1980a). Mammalian sperm-egg interaction: Identification of a glycoprotein in mouse egg zonae pellucidae possessing receptor activity for sperm. Cel/20: 873-882.

BLEIL, J.D. and WASSARMAN, P.M. (1980b). Structure and function of the zona pellucida: identification and characterization of the proteins of the mouse oocyte's zona pellucida. Dev Bio/76: 185-202.

BLEIL, J.D. and WASSARMAN, P.M. (1983). Sperm-egg interactions in the mouse: Sequence of events and induction of the acrosome reaction by a zona pellucida 
glycoprotein. Dev. Biol. 95: 317-324.

BLEIL, J.D. and WASSARMAN, P.M. (1988). Galactose at the nonreducing terminus of O-linked oligosaccharides of mouse egg zona pellucida glycoprotein ZP3 is essential for the glycoprotein's sperm receptor activity. Proc Natl Acad SCl USA 85: 6778-82.

BLEIL, J.D. and WASSARMAN, P.M. (1990). Identification of a ZP3 binding protein on acrosome-intact mouse sperm by photoaffinity crosslinking. Proc. Natt. Acad. Sci. USA 87: 5563-5567.

BOOKBINDER, L.H., CHENG, A. and BLEIL, J.D. (1995). Tissue- and speciesspecific expression of sp56, a mouse sperm fertilization protein. Science 269: 86-89.

BROWN, C.R. and HARRISON, R.A. (1978). The activation of proacrosin in spermatozoa from ram bull and boar. Biochimica et Biophysica Acta 526: 202217.

CHENG, A., LE, T., PALACIOS, M., BOOKBINDER, L.H., WASSARMAN, P.M., SUZUKI, F. and BLEIL, J.D. (1994). Sperm-egg recognition in the mouse: Characterization of sp56, a sperm protein having specific affinity for ZP3. J. Cell Biol. 125: 867-878.

COHEN, N. and WASSARMAN, P.M. (2001). Association of egg zona pellucida glycoprotein mZP3 with sperm protein sp56 during fertilization in mice. Int. J. Dev. Biol. 45: 569-76.

COONROD, S.A., HERR, J.C. and WESTHUSIN, M.E. (1996). Inhibition of bovine fertilization in vitro by antibodies to SP-10. J. Reprod. Fertil. 107: 287-97.

DAM, A.H., FEENSTRA, I., WESTPHAL, J.R., RAMOS, L., VAN GOLDE, R.J. and KREMER, J.A. (2007). Globozoospermia revisited. Hum. Reprod. Update 13: 63-75.

DEAN, J. (2007). The enigma of sperm-egg recognition in mice. Society of Reproduction and Fertility supplement 63: 359-65.

DICARLANTONIO, G. and TALBOT, P. (1988). Evidence for the sequential deployment of secretory enzymes during the normal acrosome reaction of guinea pig sperm in vitro. Gamete Research 21: 425-438.

DUCIBELLA, T., KURASAWA, S., DUFFY, P., KOPF, G.S. and SCHULTZ, R.M. (1993). Regulation of the polyspermy block in the mouse egg: maturationdependent differences in cortical granule exocytosis and zona pellucida modifications induced by inositol 1,4,5-trisphosphate and an activator of protein kinase C. Biol. Reprod. 48: 1251-1257.

EDDY, E.M. and O'BRIEN, D.A. (1994). The Spermatozoon. In The Physiology of Reproduction, Second Edition, vol. 1 (ed. KNOBIL, E. and NEILL, J. D.). Raven Press, Ltd., New York, pp.29-77.

ENSSLIN, M.A., LYNG, R., RAYMOND, A., COPLAND, S. and SHUR, B.D. (2007). Novel gamete receptors that facilitate sperm adhesion to the egg coat. Society of Reproduction and Fertility supplement 63: 367-83.

ENSSLIN, M.A. and SHUR, B.D. (2003). Identification of mouse sperm SED1, a bimotif EGF repeat and discoidin-domain protein involved in sperm-egg binding. Cel/114: 405-17.

ESCALIER, D., GALLO, J., ALBERT, M., MEDURI, G., BERMUDEZ, D., DAVID, G. and SCHREVEL, J. (1991). Human acrosome biogenesis: immunodetection of proacrosin in primary spermatocytes and of its partitioning pattern during meiosis. Development 113: 779-788.

FAWCETT, D.W. (1975a). Morphogenesis of the mammalian sperm acrosome in new perspective.. In The Functional Anatomy of the Spermatozoon., (ed. AFZELIUS, B. A.). Pergamon Press, Oxford, pp.199-210.

FAWCETT, D.W. (1975b). The mammalian spermatozoon. Dev. Biol. 44: 394-436.

FAWCETT, D.W. and HOLLENBERG, R.D. (1963). Changes in the acrosome of guinea pig spermatozoa during passage through the epididymis. Zeitschrift ffr Zellforschung 60: 276-292.

FLORMAN, H.M. and STOREY, B.T. (1982). Mouse gamete interactions: the zona pellucida is the site of the acrosome reaction leading to fertilization in vitro. Dev Bio/91: 121-30.

FLORMAN, H.M. and WASSARMAN, P.M. (1985). O-linked oligosaccharides of mouse egg ZP3 account for its sperm receptor activity. Cel/41: 313-24.

FOSTER, J.A., FRIDAY, B.B., MAULIT, M.T., BLOBEL, C., WINFREY, V.P., OLSON, G.E., KIM, K.S. and GERTON, G.L. (1997). AM67, a secretory component of the guinea pig sperm acrosomal matrix, is related to mouse sperm protein sp56 and the complement component 4-binding proteins. J. Biol. Chem.
272: 12714-12722.

FOSTER, J.A. and HERR, J.C. (1992). Interactions of human sperm acrosomal protein SP-10 with the acrosomal membranes. Biol. Reprod. 46: 981-990.

FOSTER, J.A., KLOTZ, K.L., FLICKINGER, C.J., THOMAS, T.S., WRIGHT, R.M., CASTILLO, J.R. and HERR, J.C. (1994). Human SP-10: Acrosomal distribution, processing, and fate after the acrosome reaction. Biol. Reprod. 51: 1222-1231.

GAO, Z. and GARBERS, D.L. (1998). Species diversity in the structure of zonadhesin, a sperm-specific membrane protein containing multiple cell adhesion moleculelike domains. J. Biol. Chem. 273: 3415-3421.

GAO, Z., HARUMI, T. and GARBERS, D.L. (1997). Chromosome localization of the mouse zonadhesin gene and the human zonadhesin gene (ZAN). Genomics 41 : 119-22.

GARLANDA, C., BOtTAZZI, B., BASTONE, A. and MANTOVANI, A. (2005). Pentraxins at the crossroads between innate immunity, inflammation, matrix deposition, and female fertility. Annu Rev Immuno/23: 337-66.

GERTON, G.L. (2002). Function of the sperm acrosome. In Fertilization, (ed. HARDY, D. M.). Academic Press, San Diego, CA.

GREEN, D.P. (1991). The effect of permeant and impermeant osmoticants on exocytosis in guinea pig sperm. $J$ Cel/ Sci 100: 761-9.

GREEN, D.P.L. (1978). The activation of proteolysis in the acrosome reaction of guinea-pig sperm. J. Cell Sci. 32: 153-164.

HARDY, D.M. and GARBERS, D.L. (1995). A sperm membrane protein that binds in a species-specific manner to the egg extracellular matrix is homologous to von Willebrand factor. J. Biol. Chem. 270: 26025-26028.

HARDY, D.M., ODA, M.N., FRIEND, D.S. and HUANG, T.T.F., JR. (1991). A mechanism for differential release of acrosomal enzymes during the acrosome reaction. Biochem. J. 275: 759-766.

HARTMANN, J.F., GWATKIN, R.B. and HUTCHISON, C.F. (1972). Early contact interactions between mammalian gametes in vitro: evidence that the vitellus influences adherence between sperm and zona pellucida. Proc Nat/ Acad Sci USA 69: 2767-9.

HERLYN, H. and ZISCHLER, H. (2007). Sequence evolution of the sperm ligand zonadhesin correlates negatively with body weight dimorphism in primates. Evolution; international journal of organic evolution 61: 289-98.

HERR, J.C., FLICKINGER, C.J., HOMYK, M., KLOTZ, K. and JOHN, E. (1990). Biochemical and morphological characterization of the intra-acrosomal antigen SP-10 from human sperm. Biol. Reprod. 42: 181-193.

HERR, J.C., KLOTZ, K., SHANNON, J., WRIGHT, R.M. and FLICKINGER, C.J. (1992). Purification and microsequencing of the intra-acrosomal protein SP-10. Evidence that SP-10 heterogeneity results from endoproteolytic processes. Biol. Reprod. 47: 11-20.

HONDA, A., SIRUNTAWINETI, J. and BABA, T. (2002). Role of acrosomal matrix proteases in sperm-zona pellucida interactions. Hum. Reprod. Update 8: 40512.

HOWES, L. and JONES, R. (2002). Interactions between zona pellucida glycoproteins and sperm proacrosin/acrosin during fertilization. J Reprod Immuno/53: 181-92.

HSU, Y.C. and PERIN, M.S. (1995). Human neuronal pentraxin II (NPTX2): conservation, genomic structure, and chromosomal localization. Genomics 28: 220-227.

HUANG, T.T., FLEMING, A.D. and YANAGIMACHI, R. (1981). Only acrosomereacted spermatozoa can bind to and penetrate zona pellucida: a study using the guinea pig. Journal of Experimental Zoology 217: 287-290.

HUANG, T.T.F., JR., HARDY, D., YANAGIMACHI, H., TEUSCHER, C., TUNG, K., WILD, G. and YANAGIMACHI, R. (1985). pH and protease control of acrosomal content stasis and release during the guinea pig sperm acrosome reaction. Biol. Reprod. 32: 451-462.

HYATT, H. and GWATKIN, R.B. (1988). Characterization of isolated acrosomal matrices from hamster spermatozoa. J. Reprod. Fertil. 83: 419-429.

INOUE, N., IKAWA, M., NAKANISHI, T., MATSUMOTO, M., NOMURA, M., SEYA, T. and OKABE, M. (2003). Disruption of Mouse CD46 Causes an Accelerated Spontaneous Acrosome Reaction in Sperm. Mol Cell Bio/23: 2614-22.

JONES, R. and BROWN, C.R. (1987). Identification of a zona-binding protein from boar spermatozoa as proacrosin. Exp Cell Res 171: 503-8.

KANG-DECKER, N., MANTCHEV, G.T., JUNEJA, S.C., MCNIVEN, M.A. and VAN 
DEURSEN, J.M. (2001). Lack of acrosome formation in hrb-deficient mice. Science 294: 1531-3.

KASHIWABARA, S., ARAI, Y., KODAIRA, K. and BABA, T. (1990). Acrosin biosynthesis in meiotic and postmeiotic spermatogenic cells. Biochemical and Biophysical Research Communications 173: 240-245.

KIM, K.S., CHA, M.C. and GERTON, G.L. (2001a). Mouse sperm protein sp56 is a component of the acrosomal matrix. Biol. Reprod. 64: 36-43.

KIM, K.S., FOSTER, J.A. and GERTON, G.L. (2001b). Differential release of guinea pig sperm acrosomal components during exocytosis. Biol. Reprod. 64: 148-56.

KIM, K.S. and GERTON, G.L. (2003). Differential release of soluble and matrix components: evidence for intermediate states of secretion during spontaneous acrosomal exocytosis in mouse sperm. Dev. Biol. 264: 141-52.

KOPF, G.S. (2002). Signal transduction mechanisms regulating sperm acrosomal exocytosis. In Fertilization, (ed. HARDY, D. M.). Academic Press, San Diego, pp.181-223.

KURTH, B.E., KLOTZ, K., FLICKINGER, C.J. and HERR, J.C. (1991). Localization of sperm antigen SP-10 during the six stages of the cycle of the seminiferous epithelium in man. Biol. Reprod. 44: 814-21.

KURTH, B.E., WRIGHT, R.M., FLICKINGER, C.J. and HERR, J.C. (1993). Stagespecific detection of mRNA for the sperm antigen SP-10 in human testes. Anat Rec 236: 619-25.

LARSON, J.L. and MILLER, D.J. (1999). Simple histochemical stain for acrosomes on sperm from several species. Mol Reprod Dev 52: 445-9.

LEA, I.A., SIVASHANMUGAM, P. and O'RAND, M.G. (2001). Zonadhesin: characterization, localization, and zona pellucida binding. Biol. Reprod. 65: 1691-700.

LEWIS, C.A., TALBOT, C.F. and VACQUIER, V.D. (1982). A protein from abalone sperm dissolves the egg vitelline layer by a nonenzymatic mechanism. Dev Bio/ 92: 227-39.

LIN, Y.N., ROY, A., YAN, W., BURNS, K.H. and MATZUK, M.M. (2007). Loss of zona pellucida binding proteins in the acrosomal matrix disrupts acrosome biogenesis and sperm morphogenesis. Mol Cell Bio/27: 6794-805.

LU, Q. and SHUR, B.D. (1997). Sperm from beta 1,4-galactosyltransferase-null mice are refractory to ZP3-induced acrosome reactions and penetrate the zona pellucida poorly. Development 124: 4121-31.

MANDAL, A., KLOTZ, K.L., SHETTY, J., JAYES, F.L., WOLKOWICZ, M.J., BOLLING, L.C., COONROD, S.A., BLACK, M.B., DIEKMAN, A.B., HAYSTEAD, T.A. et al. (2003). SLLP1, a unique, intra-acrosomal, non-bacteriolytic, c lysozyme-like protein of human spermatozoa. Biol. Reprod. 68: 1525-37.

MEIZEL, S. (1972). Biochemical detection and activation of an inactive form of a trypsin-like enzyme in rabbit testes. J. Reprod. Fertil. 31: 459-462.

MEIZEL, S. and DEAMER, D.W. (1978). The pH of the hamster sperm acrosome. J. Histochem. Cytochem. 26: 98-105.

MILLER, D.J., GONG, X., DECKER, G. and SHUR, B.D. (1993a). Egg cortical granule $\mathrm{N}$-acetylglucosaminidase is required for the mouse zona block to polyspermy. J. Cell Biol. 123(6 PT 1: 1431-1440.

MILLER, D.J., GONG, X. and SHUR, B.D. (1993b). Sperm require beta-Nacetylglucosaminidase to penetrate through the egg zona pellucida. Development 118: 1279-89.

MILLER, D.J., MACEK, M.B. and SHUR, B.D. (1992). Complementarity between sperm surface beta-1,4-galactosyl-transferase and egg-coat ZP3 mediates sperm-egg binding. Nature 357: 589-593.

MORALES, P. and CROSS, N.L. (1989). A new procedure for determining acrosomal status of very small numbers of human sperm. J Histochem Cytochem 37 : 1291-2.

MORALES, P., CROSS, N.L., OVERSTREET, J.W. and HANSON, F.W. (1989). Acrosome intact and acrosome-reacted human sperm can initiate binding to the zona pellucida. Dev. Biol. 133: 385-392.

MORENO, R.D., SEPULVEDA, M.S., DE IOANNES, A. and BARROS, C. (1998). The polysulphate binding domain of human proacrosin/acrosin is involved in both the enzyme activation and spermatozoa-zona pellucida interaction. Zygote 6: 75-83.

MORI, E., BABA, T., IWAMATSU, A. and MORI, T. (1993). Purification and characterization of a 38-kDa protein, sp38, with zona pellucida-binding property from porcine epididymal sperm. Biochemical and Biophysical Research Communications 196: 196-202.
MORI, E., KASHIWABARA, S.-I., BABA, T., INAGAKI, Y. and MORI, T. (1995). Amino acid sequences of porcine sp38 and proacrosin required for binding to the zona pellucida. Dev. Biol. 168: 575-583.

NAGAE, T., YANAGIMACHI, R., SRIVASTAVA, P.N. and YANAGIMACHI, H. (1986). Acrosome reaction in human spermatozoa. Fertil. Steril. 45: 701-7.

NAGDAS, S.K., WINFREY, V.P. and OLSON, G.E. (1996a). Identification of hydrolase binding activities of the acrosomal matrix of hamster spermatozoa. Biol. Reprod. 55: 1405-1414.

NAGDAS, S.K., WINFREY, V.P. and OLSON, G.E. (1996b). Proacrosin-acrosomal matrix binding interactions in ejaculated bovine spermatozoa. Biol. Reprod. 54: 111-21.

NAKANISHI, T., IKAWA, M., YAMADA, S., PARVINEN, M., BABA, T., NISHIMUNE, Y. and OKABE, M. (1999). Real-time observation of acrosomal dispersal from mouse sperm using GFP as a marker protein. FEBS Lett. 449: 277-83.

NAKANISHI, T., IKAWA, M., YAMADA, S., TOSHIMORI, K. and OKABE, M. (2001). Alkalinization of Acrosome Measured by GFP as a pH Indicator and Its Relation to Sperm Capacitation. Dev Bio/237: 222-31.

NOLAND, T.D. (1990). Regulation of acrosomal matrix dispersion in digitoninpermeabilized guinea pig spermatozoa. Biol. Reprod. 42: 252-259.

NOLAND, T.D., DAVIS, L.S. and OLSON, G.E. (1989). Regulation of proacrosin conversion in isolated guinea pig sperm acrosomal apical segments. J. Biol. Chem. 264: 13586-13590.

NOLAND, T.D., FRIDAY, B.B., MAULIT, M.T. and GERTON, G.L. (1994). The sperm acrosomal matrix contains a novel member of the pentaxin family of calcium-dependent binding proteins. J. Biol. Chem. 269: 32607-32614.

NUZZO, N.A., ANDERSON, R.A., JR. and ZANEVELD, L.J.D. (1990). Proacrosin activation and acrosin release during the guinea pig acrosome reaction. Mol. Reprod. Dev. 25: 52-60.

OLSON, G.E. and WINFREY, V.P. (1994). Structure of acrosomal matrix domains of rabbit sperm. Journal of Structural Biology 112: 41-48.

OLSON, G.E., WINFREY, V.P., BI, M., HARDY, D.M. and NAGDAS, S.K. (2004). Zonadhesin assembly into the hamster sperm acrosomal matrix occurs by distinct targeting strategies during spermiogenesis and maturation in the epididymis. Biol. Reprod. 71: 1128-34.

OLSON, G.E., WINFREY, V.P. and DAVENPORT, G.R. (1988). Characterization of matrix domains of the hamster acrosome. Biol. Reprod. 39: 1145-1158.

OLSON, G.E., WINFREY, V.P., NEFF, J.C., LUKAS, T.J. and NAGDAS, S.K. (1997). An antigenically related polypeptide family is a major structural constituent of a stable acrosomal matrix assembly in bovine spermatozoa. Biol. Reprod. 57: 325-34.

OLSON, G.E., WINFREY, V.P., WINER, M.A. and DAVENPORT, G.R. (1987). Outer acrosomal membrane of guinea pig spermatozoa: Isolation and structural characterization. Gamete Research 17: 77-84.

REID, M. and BLOBEL, C.P. (1994). Apexin, an acrosomal pentaxin. J. Biol. Chem. 269: 32615-32620.

RICHARDSON, R.T. and O'RAND, M.G. (1996). Site-directed mutagenesis of rabbit proacrosin. Identification of residues involved in zona pellucida binding. J. Biol. Chem. 271: 24069-74.

ROCKWELL, P.L. and STOREY, B.T. (2000). Kinetics of onset of mouse sperm acrosome reaction induced by solubilized zona pellucida: fluorimetric determination of loss of $\mathrm{pH}$ gradient between acrosomal lumen and medium monitored by dapoxyl (2- aminoethyl) sulfonamide and of intracellular $\mathrm{Ca}(2+)$ changes monitored by fluo-3. Mol Reprod Dev 55: 335-49.

SALING, P.M., SOWINSKI, J. and STOREY, B.T. (1979). An ultrastructural study of epididymal mouse spermatozoa binding to the zonae pellucidae in vitro: Sequential relationship to the acrosome reaction. Journal of Experimental Zoology 209: 229-238.

SALING, P.M. and STOREY, B.T. (1979). Mouse gamete interactions during fertilization in vitro: Chlortetracylcine as a fluorescent probe for the mouse sperm acrosome reaction. J. Cell Biol. 83: 544-555.

SCHILL, W.B. (1991). Some disturbances of acrosomal development and function in human spermatozoa. Hum. Reprod. 6: 969-978.

SHETTY, J., WOLKOWICZ, M.J., DIGILIO, L.C., KLOTZ, K.L., JAYES, F.L., DIEKMAN, A.B., WESTBROOK, V.A., FARRIS, E.M., HAO, Z., COONROD, S.A. et al. (2003). SAMP14, a novel, acrosomal membrane-associated, 
glycosylphosphatidylinositol-anchored member of the Ly-6/urokinase-type plasminogen activator receptor superfamily with a role in sperm-egg interaction. $J$. Biol. Chem. 278: 30506-15.

SHUR, B.D. and HALL, N.G. (1982). A role for mouse sperm surface galactosyltransferase in sperm binding to the egg zona pellucida. J. Cell Biol. 95: 574-9.

SOTOMAYOR, R.E. and HANDEL, M.A. (1986). Failure of acrosome assembly in a male sterile mouse mutant. Biol. Reprod. 34: 171-182.

STOCK, C.E. and FRASER, L.R. (1987). The acrosome reaction in human sperm from men of proven fertility. Hum. Reprod. 2: 109-19.

SUZUKI-TOYOTA, F., MAEKAWA, M., CHENG, A. and BLEIL, J.D. (1995). Immunocolloidal gold labeled surface replica, and its application to detect sp56, the egg recognition and binding protein, on the mouse spermatozoon. J. Electron Microsc. 44: 135-139.

TALBOT, P. and DICARLANTONIO, G. (1985). Cytochemical localization of dipeptidyl peptidase II (DPP-II) in mature guinea pig sperm. J. Histochem. Cytochem. 33: 1169-1172.

TANII, I., ARAKI, S. and TOSHIMORI, K. (1994). Intra-acrosomal organization of a 90-kilodalton antigen during spermiogenesis in the rat. Cell Tissue Res277:617.

TESARIK, J., DRAHORAD, J., TESTART, J. and MENDOZA, C. (1990). Acrosin activation follows its surface exposure and precedes membrane fusion in human sperm acrosome reaction. Development 110: 391-400.

TOLLNER, T.L., YUDIN, A.I., CHERR, G.N. and OVERSTREET, J.W. (2000). Soybean trypsin inhibitor as a probe for the acrosome reaction in motile cynomolgus macaque sperm. Zygote 8: 127-37.

TSUI, C.C., COPELAND, N.G., GILBERT, D.J., JENKINS, N.A., BARNES, C. and WORLEY, P.F. (1996). Narp, a novel member of the pentraxin family, promotes neurite outgrowth and is dynamically regulated by neuronal activity. Journal of Neuroscience 16: 2463-2478.

VALDIVIA, M., SILLERICO, T., DE IOANNES, A. and BARROS, C. (1999). Proteolytic activity of rabbit perivitelline spermatozoa. Zygote 7: 143-9.

WASSARMAN, P.M. (2005). Contribution of mouse egg zona pellucida glycoproteins to gamete recognition during fertilization. J Cell Physio/204: 388-91.

WESTBROOK-CASE, V.A., WINFREY, V.P. and OLSON, G.E. (1994). A domainspecific 50-kilodalton structural protein of the acrosomal matrix is processed and released during the acrosome reaction in the guinea pig. Biol. Reprod. 51: $1-13$.
WESTBROOK-CASE, V.A., WINFREY, V.P. and OLSON, G.E. (1995). Sorting of the domain-specific acrosomal matrix protein AM50 during spermiogenesis in the guinea pig. Dev. Biol. 167: 338-349.

WILLIAMS, R.M. and JONES, R. (1991). Binding of zona pellucida glycoproteins to sperm proacrosin. Biochem. Soc. Trans. 19: 412S.

WILLIAMS, S.A., XIA, L., CUMMINGS, R.D., MCEVER, R.P. and STANLEY, P. (2007). Fertilization in mouse does not require terminal galactose or $\mathrm{N}$ acetylglucosamine on the zona pellucida glycans. J Cel/ Sci120: 1341-9.

WOLKOWICZ, M.J., DIGILIO, L., KLOTZ, K., SHETTY, J., FLICKINGER, C.J. and HERR, J.C. (2007). Equatorial Segment Protein (ESP) is a Human Alloantigen Involved in Sperm-Egg Binding and Fusion. J Androl.

WOLKOWICZ, M.J., SHETTY, J., WESTBROOK, A., KLOTZ, K., JAYES, F., MANDAL, A., FLICKINGER, C.J. and HERR, J.C. (2003). Equatorial segment protein defines a discrete acrosomal subcompartment persisting throughout acrosomal biogenesis. Biol. Reprod. 69: 735-45.

YAMAGATA, K., MURAYAMA, K., KOHNO, N., KASHIWABARA, S. and BABA, T. (1998a). p-Aminobenzamidine-sensitive acrosomal protease(s) other than acrosin serve the sperm penetration of the egg zona pellucida in mouse. Zygote 6: 311-9.

YAMAGATA, K., MURAYAMA, K., OKABE, M., TOSHIMORI, K., NAKANISHI, T., KASHIWABARA, S. and BABA, T. (1998b). Acrosin accelerates the dispersal of sperm acrosomal proteins during acrosome reaction. J. Biol. Chem. 273: 10470-4.

YAMASHITA, M., YAMAGATA, K., TSUMURA, K., NAKANISHI, T. and BABA, T. (2007). Acrosome reaction of mouse epididymal sperm on oocyte zona pellucida. J Reprod Dev 53: 255-62.

YANAGIMACHI, R. (1994). Mammalian fertilization. In The Physiology of Reproduction, (ed. KNOBIL, E. and NEILL, J. D.). Raven Press, Ltd., New York, pp.189-317.

YI, L.S. and POLAKOSKI, K.L. (1992). Proacrosin binding protein: immunocomparative studies in boar, bovine, hamster, human and ram. $J$ Reprod Immuno/21: 309-20.

YU, Y., XU, W., YI, Y.J., SUTOVSKY, P. and OKO, R. (2006). The extracellular protein coat of the inner acrosomal membrane is involved in zona pellucida binding and penetration during fertilization: characterization of its most prominent polypeptide (IAM38). Dev Bio/290: 32-43.

YUDIN, A.I., GOTTLIEB, W. and MEIZEL, S. (1988). Ultrastructural studies of the early events of the human sperm acrosome reaction as initiated by human follicular fluid. Gamete Res 20: 11-24. 


\section{Related, previously published Int. J. Dev. Biol. articles}

See our recent Special Issue Developmental Biology in Poland edited by Tarkowski, Maleszewski and Kloc at: http://www.ijdb.ehu.es/web/contents.php?vol=52\&issue=2-3

See our recent Special Issue Ear Development edited by Fernando Giraldez and Bernd Fritzsch at: http://www.ijdb.ehu.es/web/contents.php?vol=51\&issue=6-7

Defective calcium release during in vitro fertilization of maturing oocytes of LT/Sv mice Karolina Archacka, Anna Ajduk, Pawel Pomorski, Katarzyna Szczepanska, Marek Maleszewski and Maria A. Ciemerych Int. J. Dev. Biol. (2008) 52: doi: 10.1387/ijdb.072397ka

The role of ion fluxes in polarized cell growth and morphogenesis: the pollen tube as an experimental paradigm Erwan Michard, Filipa Alves and José A. Feijó

Int. J. Dev. Biol. (2008) 52: doi: 10.1387/ijdb.072296em

Expression of protocadherin 18 in the CNS and pharyngeal arches of zebrafish embryos Fumitaka Kubota, Tohru Murakami, Yuki Tajika and Hiroshi Yorifuji

Int. J. Dev. Biol. (2008) 52: 397-405

Hypomethylation of paternal DNA in the late mouse zygote is not essential for development Zbigniew Polanski, Nami Motosugi, Chizuko Tsurumi, Takashi Hiiragi and Steffen Hoffmann

Int. J. Dev. Biol. (2008) 52: 295-298

Genetic control of gamete quality in the mouse - a tribute to Halina Krzanowska Jozefa Styrna

Int. J. Dev. Biol. (2008) 52: 195-199

Early mammalian embryo: my love. An interview with Andrzej K. Tarkowski Marek Maleszewski and Andrzej K. Tarkowski

Int. J. Dev. Biol. (2008) 52: 163-169

Animal reproduction biotechnology in Poland

Zdzislaw Smorag, Lucyna Katska-Ksiazkiewicz, Maria Skrzyszowska, Jacek Jura, Barbara Gajda and Michal Bochenek Int. J. Dev. Biol. (2008) 52: 151-155

Mammalian and avian embryology at Warsaw University (Poland) from XIX century to the present

Andrzej K. Tarkowski, Marek Maleszewski, Teresa Rogulska, Maria A. Ciemerych and Ewa Borsuk

Int. J. Dev. Biol. (2008) 52: 121-134

CpZPC, a newt ZPC molecule, localizes to the inner surface of the egg envelope.

Youko Makabe-Kobayashi, Etsuko Kudaira, Akihiko Watanabe and Kazuo Onitake Int. J. Dev. Biol. (2003) 47: 51-58

Association of egg zona pellucida glycoprotein mZP3 with sperm protein sp56 during fertilization in mice.

$\mathrm{N}$ Cohen and $\mathrm{P} M$ Wassarman

Int. J. Dev. Biol. (2001) 45: 569-576

Analysis of polysulfate-binding domains in porcine proacrosin, a putative zona adhesion protein from mammalian spermatozoa.

$S$ Jansen, M Quigley, W Reik and R Jones

Int. J. Dev. Biol. (1995) 39: 501-510

Egg-jelly signal molecules for triggering the acrosome reaction in starfish spermatozoa.

M Hoshi, T Nishigaki, A Ushiyama, T Okinaga, K Chiba and M Matsumoto Int. J. Dev. Biol. (1994) 38: 167-174

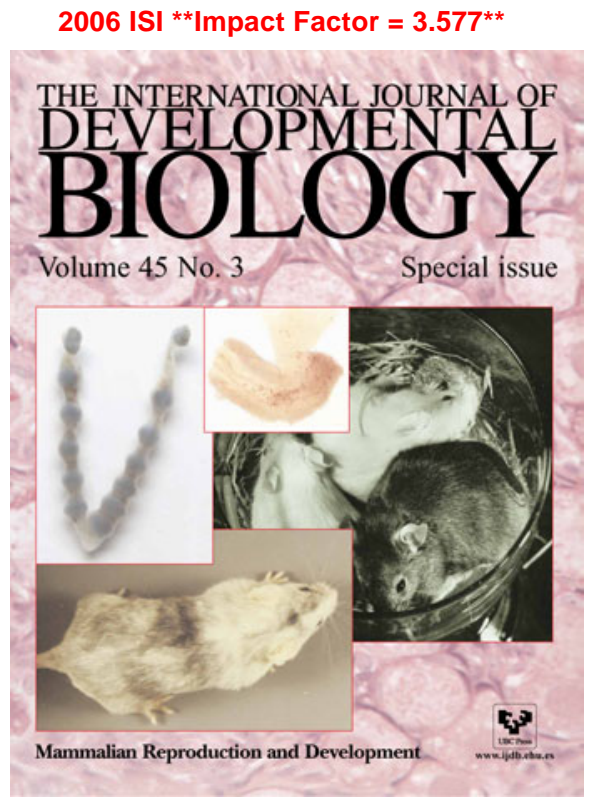

